\title{
Analisis Tegangan von Mises dan Safety Factor pada Chassis Kendaraan Listrik Tipe In-Wheel
}

\author{
Febrian Arif Budiman*, Angga Septiyanto, Sudiyono, Ari Dwi Nur Indriawan Musyono, Rizki Setiadi \\ Jurusan Teknik Mesin, Fakultas Teknik, Universitas Negeri Semarang \\ Kampus Unnes Sekaran \\ *Email: febrian@mail.unnes.ac.id
}

Diterima: 15-10-2020; Direvisi: 04-04-2021; Dipublikasi: 27-04-2021

\begin{abstract}
Abstrak
Transportasi merupakan kebutuhan setiap manusia untuk menunjang pekerjaannya. Saat ini kendaraan ramah lingkungan yang banyak dikembangkan adalah kendaraan listrik. Kendaraan listrik dianggap bebas emisi dan dapat mempengaruhi kondisi lingkungan. Salah satu komponen penting pada kendaraan listrik adalah chassis. Untuk itu, diperlukan desain chassis yang tepat agar keamanan dan kenyamanan kendaraan terjamin. Dalam perkembangan kendaraan listrik, model penggerak motor listrik langsung ditempatkan pada roda atau yang sering disebut dengan inwheel. Tujuan penelitian ini adalah (1) Mendesain chassis pada kendaraan listrik tipe in-wheel, (2) Menganalisis tegangan von mises dari desain chassis kendaraan listrik tipe in-wheel, (3) Menganalisis safety factor pada kendaraan listrik ramah lingkungan tipe in-wheel. Metode penelitian menggunakan simulasi. Simulasi dilakukan dengan menggunakan software Autodesk Inventor. Material yang digunakan yaitu baja AISI 1018 HR. Hasil Penelitian menunjukkan telah dihasilkan desain chassis untuk kendaraan listrik 6 orang penumpang. Tegangan von mises pada chassis minimum sebesar 0 dan maksimal 20,33 MPa, displacement minimum sebesar 0 dan maksimum sebesar 0,22, serta nilai safety factor minimum sebesar 12,3 dan maksimum sebesar 15. Berdasarkan hasil penelitian desain chassis yang telah dibuat dikategorikan aman secara teknis.
\end{abstract}

Kata kunci: Desain; analisis; sasis; kendaraan listrik; in-wheel

\begin{abstract}
Transportation is a necessity for every human being to support his work. Currently, the most environmentally friendly vehicles that are being developed are electric vehicles. Electric vehicles are considered emission-free and can affect environmental conditions. One of the important components of an electric vehicle is the chassis. For that, we need the right chassis design so that the safety and comfort of the vehicle are guaranteed. In the development of electric vehicles, the electric motor drive model is directly placed on the wheel or what is often referred to as the in-wheel. The objectives of this study are (1) to design the chassis of an in-wheel type electric vehicle, (2) to analyze the von Mises voltage of the in-wheel type electric vehicle chassis design, (3) to analyze the safety factor for environmentally friendly in-wheel type electric vehicles. The research method uses simulation. Simulations were carried out using Autodesk Inventor software. The material used is AISI 1018 HR steel. The results showed that the chassis design for the 6th passenger electric vehicle has been produced. von mises stress on chassis minimum of 0 and a maximum of $20.33 \mathrm{MPa}$, a minimum displacement of 0 and a maximum of 0.22, and a minimum safety factor value of 12.3 and a maximum of 15 . Based on the results, the chassis design is safely categorized technically.
\end{abstract}

Keywords: Design; analysis; chassis; electric vehicle; in-wheel

\section{Pendahuluan}

Transportasi merupakan kebutuhan setiap manusia untuk menunjang pekerjaannya. Salah satu bentuk transportasi darat adalah kendaraan seperti sepeda, sepeda motor, mobil, kereta, dan lain-lain. Mobil merupakan kendaraan yang menggunakan mesin pembakaran dalam. Mesin pembakaran dalam ini memiliki kelemahan dalam polusi yang dihasilkan. Polusi yang dihasilkan oleh kendaraan bermotor dapat menyebabkan banyak kerugian. Kerugian akibat emisi antara lain kerugian kesehatan, lingkungan, dan dampak ekonomi [1-3]. Selain itu, integrasi energi terbarukan ke transportasi telah meningkat dengan cepat karena ketidakpastian dalam cadangan minyak bumi dan meningkatnya pencemaran lingkungan yang disebabkan oleh emisi karbon dioksida. Menurut prediksi penyediaan dan konsumsi Bahan Bakar Minyak (BBM) 
untuk tahun 2017 sampai 2025 tidak dapat memenuhi kebutuhan BBM dalam negeri [4]. Untuk mengurangi polusi akibat penggunaan kendaaran yang menggunakan mesin pembakaran dalam, mesin mobil telah menggunakan motor listrik atau sering disebut kendaraan listrik.

Listrik sebagai energi terbarukan adalah alternatif utama untuk minyak bumi dalam transportasi. Karakteristik kendaraan listrik menjadi kendaraan ramah lingkungan karena nol emisi karbon dioksida membuatnya menjadi alternatif yang baik untuk menggantikan mesin pembakaran internal konvensional [5]. Kendaraan listrik terdiri dari chassis yang menahan semua beban, motor listrik yang menjalankan roda dan baterai yang memasok energi ke motor listrik. Pengendalian dan pemantauan kinerja keseluruhan kendaraan ditangani oleh sistem manajemen baterai dan sistem pengontrol motor [6]. Kekhawatiran atas perubahan iklim dan pengurangan emisi gas rumah kaca, dan ketergantungan ekonomi pada sumber energi asing, juga telah menjadi inisiatif untuk penelitian ekstensif tentang penggunaan kendaraan listrik sebagai alternatif [7-9].

Dalam mengembangkan kendaraan listrik, komponen penting pada kendaraan adalah chassis. Chassis atau rangka kendaraan harus mempunyai kontruksi yang kuat untuk menopang beban kendaraan. Selain kontruksi yang kuat, chassis juga harus ringan agar dapat mengefektifkan tenaga yang dihasilkan dari sistem penghasil tenaga. Chassis pada kendaraan memiliki masing-masing jenis sesuai dengan fungsi kendaraan itu sendiri. Pada kendaraan listrik chassis yang banyak digunakan adalah ladder frame. Chassis jenis ini dapat menopang kendaraan dan menyediakan dudukan yang kuat dari berat beban serta kelebihan utamanya terletak pada kekuatan. Selain itu, chassis jenis ini juga mudah didesain [10].

Komponen kendaraan listrik yang penting lainnya adalah motor listrik dan baterai. Motor yang dapat digunakan sebagai penggerak kendaraan listrik meliputi Brushed DC Motor, Permanent Magnet Brushless DC Motor (BLDC), Permanent Magnet Synchronous Motor (PMSM), Motor Induksi, Switched Reluctance Motor (SRM), dan Synchronous Reluctance Motor (SynRM) [11]. Sedangkan jenis baterai yang dapat digunakan untuk kendaraan listrik meliputi baterai lead acid (aki), NiMH, Lithium-Ion, Lithium Polymer (Li-Po) Nickel Zinc, dan Nickel-Cadmium [12]. Pada perkembangannya kendaraan listrik memiliki beberapa tipe. Tipe ini berdasarkan penempatan motor listrik dan sistem pemindah daya. Perbedaan konfigurasi pada kendaraan listrik ditunjukkan pada Gambar 1 [11-13].

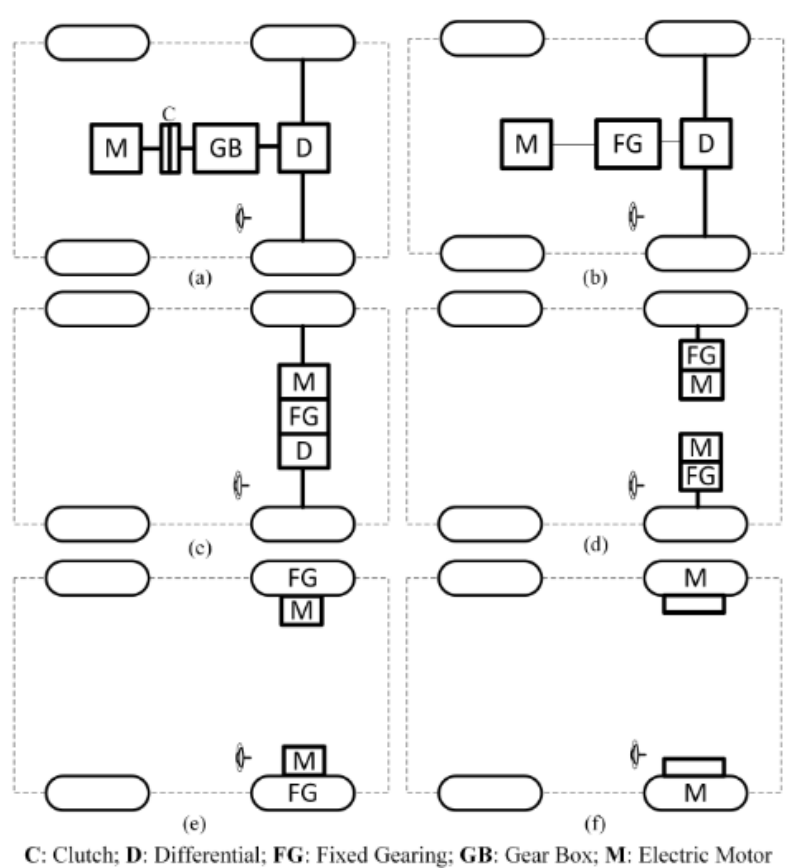

Gambar 1. Perbedaan konfigurasi pada kendaraan listrik 
Saat ini kendaraan listrik yang banyak dikembangkan adalah tipe in-wheel [14-18]. Penelitian tentang chassis pada kendaraan listrik akan meningkatkan performa kendaraan. Selain mendapatkan desain yang sesuai, juga dapat diaplikasikan pada kendaraan listrik yang ramah lingkungan. Untuk itu perlu adanya penelitian tentang tegangan von mises dan safety factor chassis pada kendaraan listrik in-wheel agar menghasilkan rangka yang aman.

Analisis tegangan penting dalam mengetahui tegangan, deformasi kelelahan (fatigue) dan predikasi masa pakai yang dialami komponen untuk menentukan titik stress tertinggi yang biasa dikenal sebagai titik kritis yang mengawali kegagalan. Titik kritis ini adalah salah satu faktor yang dapat menyebabkan fatigue failure. Besarnya tegangan kerja saat chassis menerima beban dapat digunakan untuk memprediksi masa pakai chassis. Lokasi titik tekanan kritis sangat penting sehingga pemasangan komponen seperti mesin, suspensi, transmisi dan banyak lagi dapat ditentukan dan dioptimalkan [19]. Artikel ini membahas tentang desain chassis pada kendaraan listrik tipe in-wheel, tegangan von mises dari desain chassis kendaraan listrik tipe in-wheel, serta safety factor pada kendaraan listrik ramah lingkungan tipe inwheel.

\section{2. $\quad$ Metode}

Metode pelaksanaan dalam penelitian ini menggunakan metode simulasi. Penelitian dilakukan melalui tiga tahap. Tahap pertama yaitu kajian pustaka dan observasi, tahap kedua yaitu perancangan, dan simulasi, dan tahap ketiga yaitu analisis hasil simulasi. Simulasi yang dilakukan menggunakan software Autodesk Inventor 2017. Penelitian ini masih dalam tahap pengembangan sasis untuk kendaraan listrik ramah lingkungan tipe in-wheel. Diagram alir penelitian ditunjukkan pada Gambar 2.

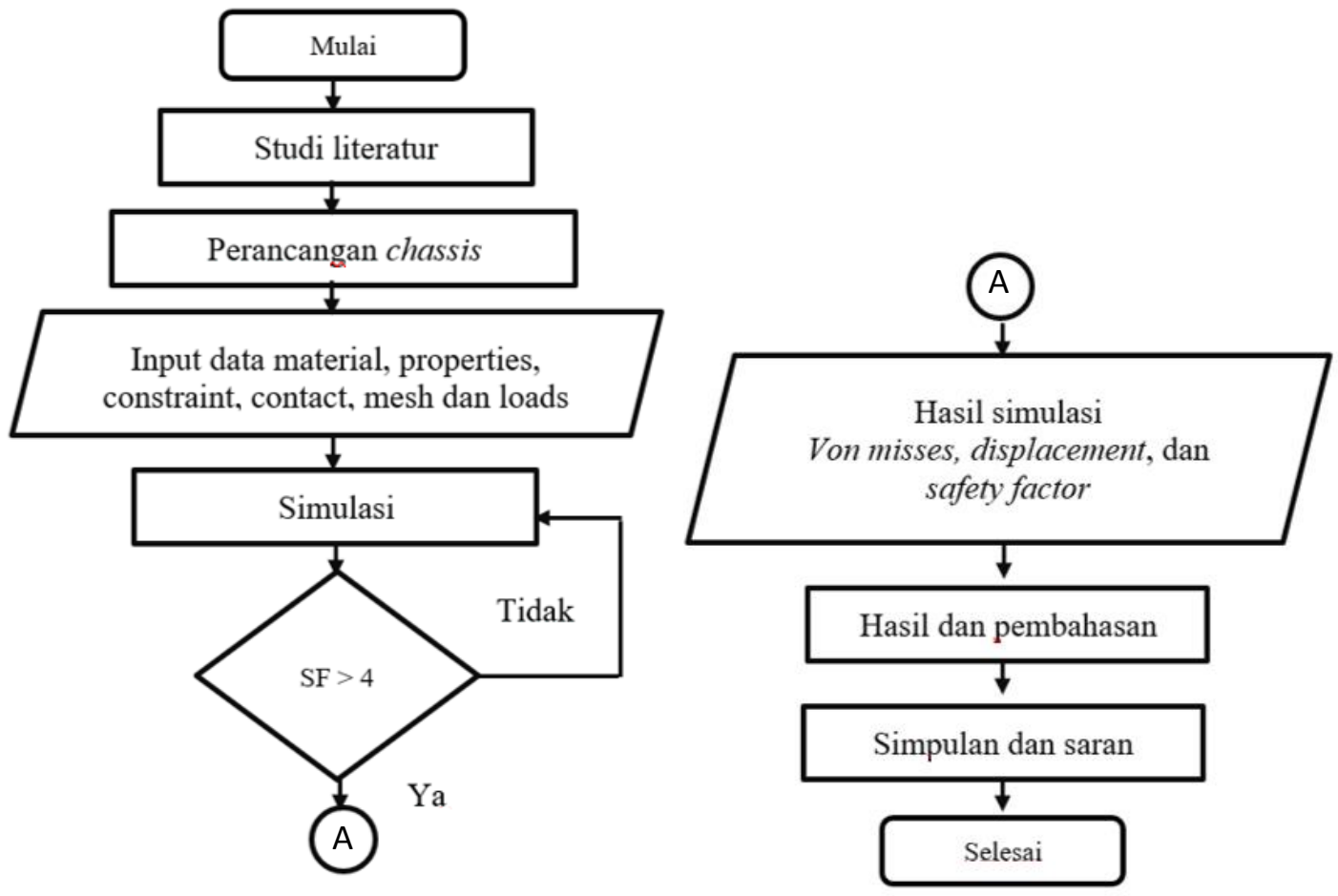

Gambar 2. Diagram alir penelitian 
Febrian Arif Budiman dkk /Jurnal Rekayasa Mesin

p-ISSN: 1411-6863, e-ISSN: 2540-7678

Vol.16|No.1|100-108|April|2021

\section{Hasil dan Pembahasan}

Penelitian dilakukan dengan mendesain dan mensimulasikan tegangan von mises dan safety factor pada chasis untuk mengetahui tingkat keamanannya. Dari desain yang telah dibuat chassis dapat digunakan untuk menampung 6 orang penumpang dan komponen pendukung pada kendaraan. Desain chassis ditunjukkan pada Gambar 3.

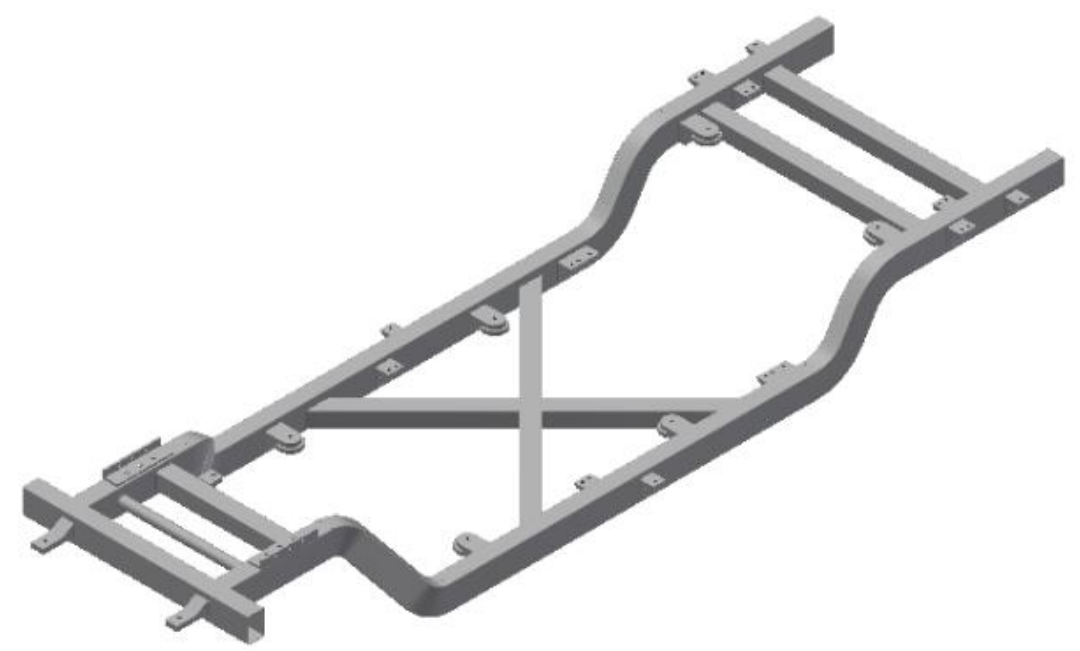

Gambar 3. Desain chassis kendaraan ramah lingkungan tipe in-wheel

Material yang digunakan saat simulasi tegangan von mises, displacement, dan tingkat keamanan menggunakan baja AISI 1018 HR. Spesifikasi material ditunjukkan pada Tabel 1. Spesifikasi detail desain chassis ditunjukkan pada Tabel 2. Pembebanan pada chassis kendaraan secara rinci ditunjukkan pada Tabel 3 dan Gambar 4. Hasil simulasi tegangan von mises pada chassis ditunjukkan pada Gambar 5. Nilai von mises stress tertinggi sebesar 20,33 MPa.

Tabel 1. Material properties

\begin{tabular}{ccccc}
\hline Nama Material & Modulus young & Yield strength & Ultimate strength & Density \\
\hline Baja AISI 1018 HR & $207 \mathrm{GPa}$ & $250 \mathrm{MPa}$ & $354 \mathrm{MPa}$ & $7,87 \mathrm{~g} / \mathrm{cm}^{3}$ \\
\hline
\end{tabular}

Tabel 2. Detail desain chassis kendaraan listrik

\begin{tabular}{cll}
\hline No & Material dan Dimensi & Spesifikasi \\
\hline 1. & Material & Steel AISI 1018 106 HR \\
2. & Rectangular Long member & $120 \times 80 \times 3 \mathrm{~mm}$ \\
3. & Circular Cross Member & $42,4 \times 3 \mathrm{~mm}$ \\
4. & Square Cross member & $80 \times 80 \times 3 \mathrm{~mm}$ \\
5. & Panjang & $3828 \mathrm{~mm}$ \\
6. & Lebar & $1180 \mathrm{~mm}$ \\
\hline
\end{tabular}

Tabel 3. Pembebanan pada Chassis

\begin{tabular}{|c|c|c|}
\hline Beban & Komponen & Beban \\
\hline F1 & Master Rem dan Komponen Kemudi & $108 \mathrm{~N}$ \\
\hline $\mathrm{F} 2$ & Body Kendaraan & $588,6 \mathrm{~N}$ \\
\hline F3 & Baterai & $402,21 \mathrm{~N}$ \\
\hline $\mathrm{F} 4$ & Penumpang dan Jok Depan & $1471,5 \mathrm{~N}$ \\
\hline F5 & Controller & $19,62 \mathrm{~N}$ \\
\hline F6 & Penumpang dan Jok Tengah & $1471,5 \mathrm{~N}$ \\
\hline F7 & Penumpang dan Jok Belakang & $1471,5 \mathrm{~N}$ \\
\hline
\end{tabular}


Febrian Arif Budiman dkk /Jurnal Rekayasa Mesin p-ISSN: 1411-6863, e-ISSN: 2540-7678

Vol.16|No.1|100-108|April|2021

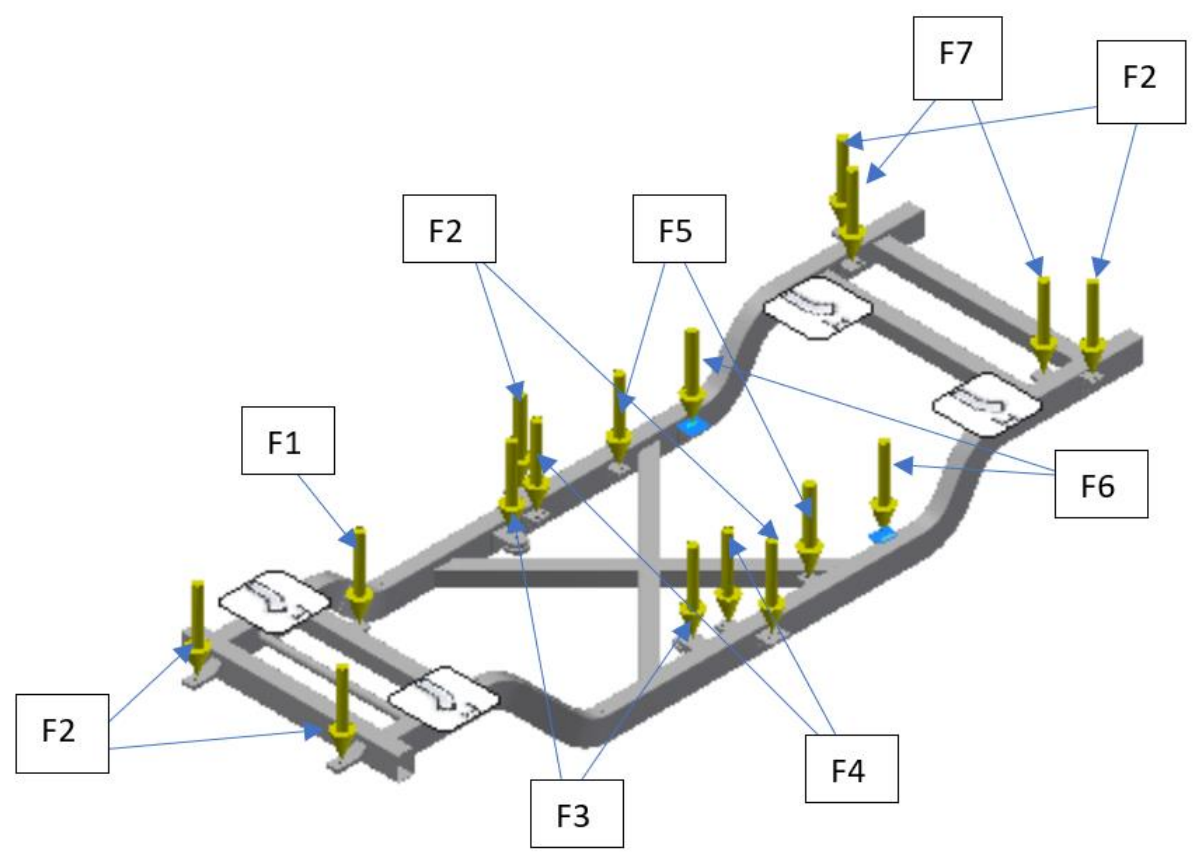

Gambar 4. Distribusi pembebanan pada chassis

Type: Von Mises Stress

Unit: $\mathrm{MPa}$

$13 / 05 / 2020,03: 50: 09$

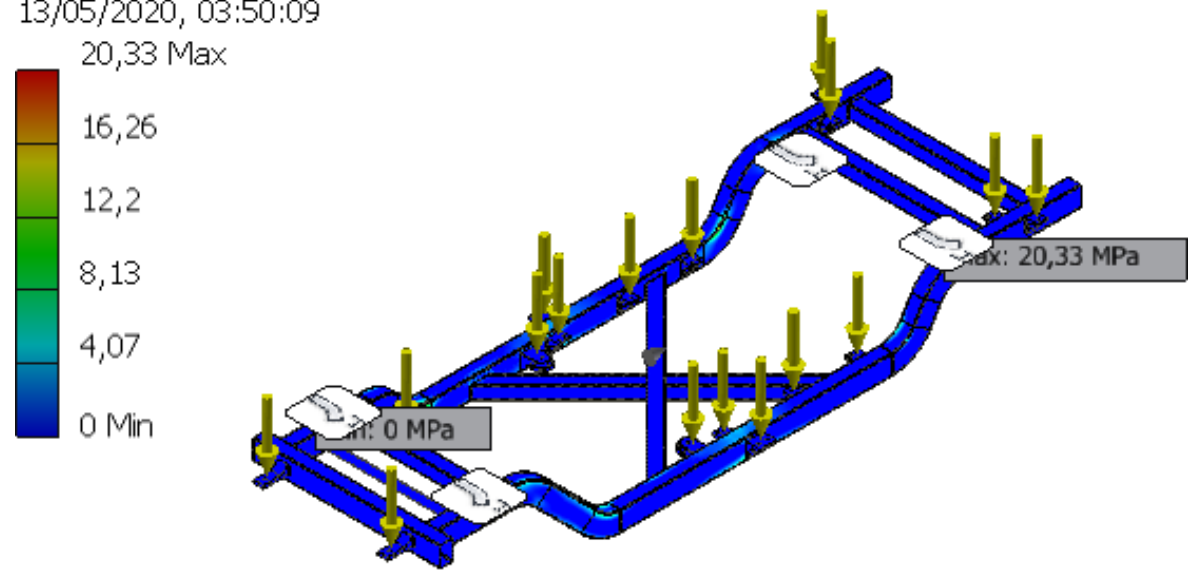

$\overbrace{x}^{x}$

Gambar 5. Hasil analisis tegangan von mises pada chassis kendaraan

Hasil simulasi displacement pada chassis ditunjukkan pada Gambar 6 (a-b). Gambar 6 (a) menunjukkan displacement tertinggi berada pada dudukan kursi dan penumpang bagian depan sebesar 0,22. Hasil simulasi safety factor pada chassis ditunjukkan pada Gambar 6 (b). 
Type: Displacement

Unit: $\mathrm{mm}$

$13 / 05 / 2020,03: 50: 28$
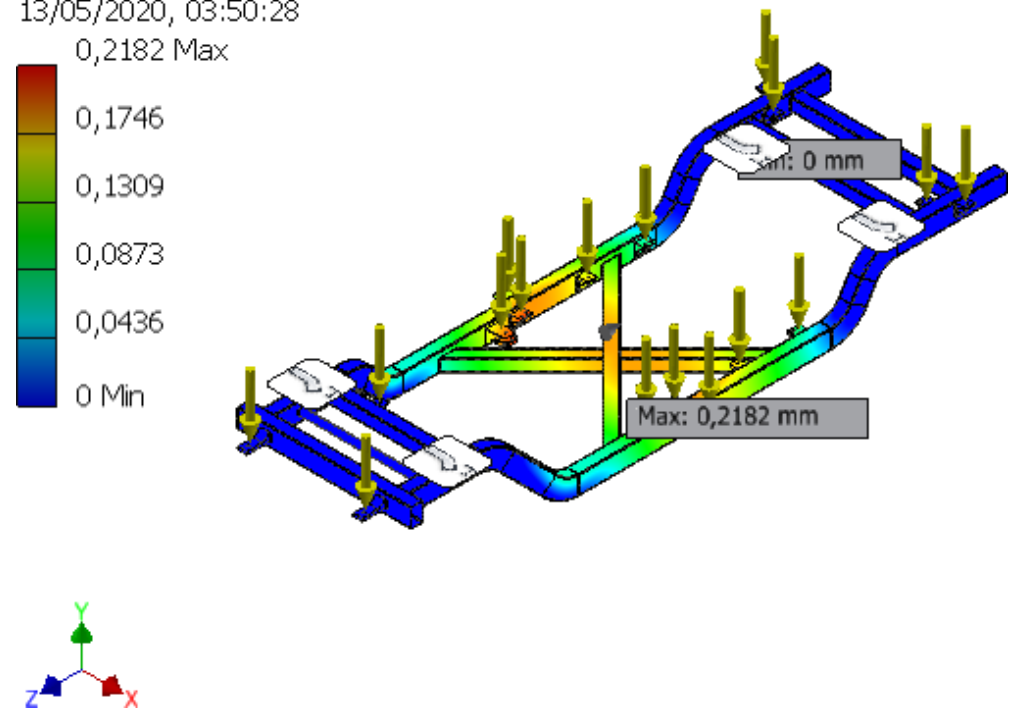

(a)

Type: Safety Factor

Unit: ul

13/05/2020, 03:50:19
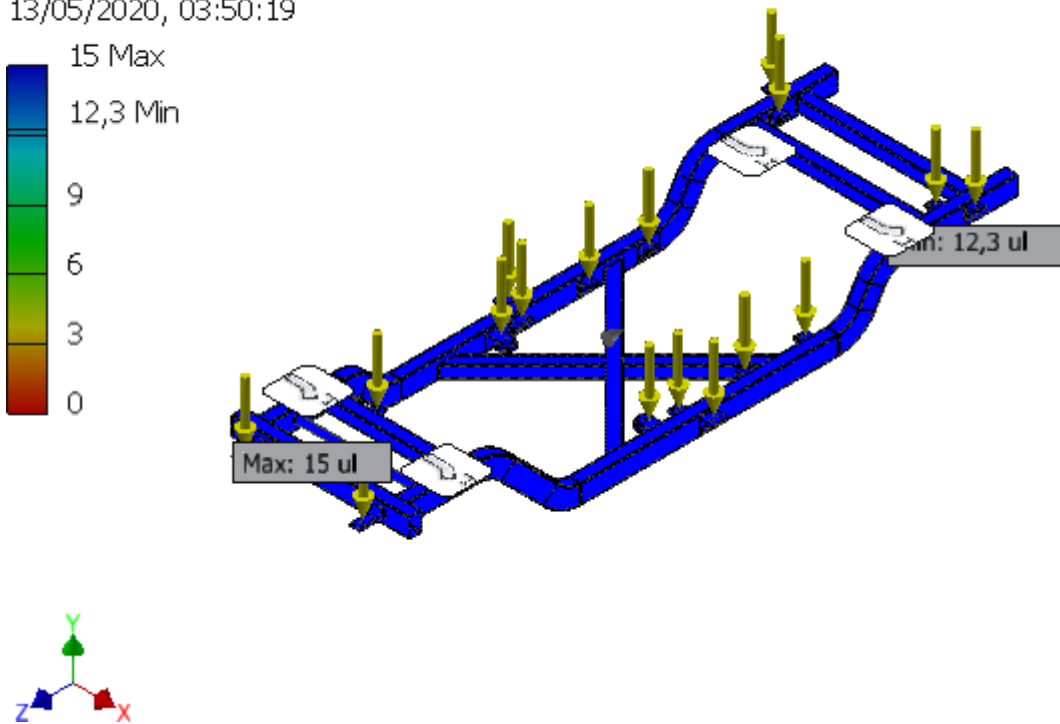

(b)

Gambar 6. Hasil analisis (a) displacement pada chassis kendaraan dan (b) safety factor pada chassis kendaraan

Berdasarkan hasil simulasi menggunakan software Autodesk Inventor tegnagan von mises maksimum di daerah las pada dudukan kursi tengah, Displacement maksimum di dudukan kursi depan, safety factor minimum di daerah las pada dudukan kursi tengah. Agar simulasi lebih akurat pada bagain yang kritis, perlu dilakukan control mesh menggunakan fitur mesh view pada software Autodesk Inventor. Hasil simulasi tegangan von mises, displacement, dan safety factor ditunjukkan pada Gambar 7 (a-c). Safety factor minimum berada pada area dudukan bodi dan suspensi belakang sebesar 12,3. Secara rinci hasil simulasi stress analisis ditunjukkan pada Tabel 4. 
Febrian Arif Budiman dkk /Jurnal Rekayasa Mesin

p-ISSN: 1411-6863, e-ISSN: 2540-7678

Vol.16|No.1|100-108|April|2021

Nodes:893762

Elements:464237

Type: Von Mises Stress

Unit: $\mathrm{MPa}$

13/05/2020, 03:56:19

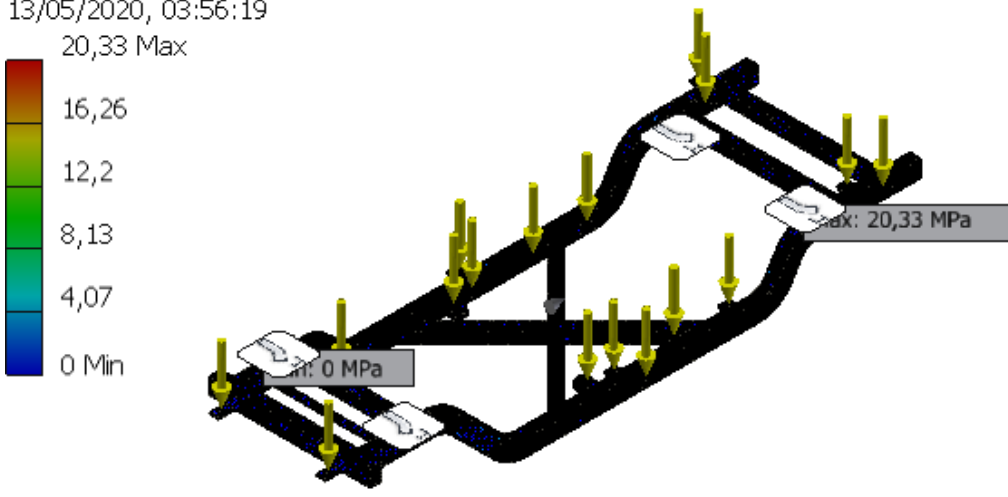

(a)

Nodes: 893762

Elements:464237

Type: Displacement

Unit: $\mathrm{mm}$

$13 / 05 / 2020,03: 57: 01$

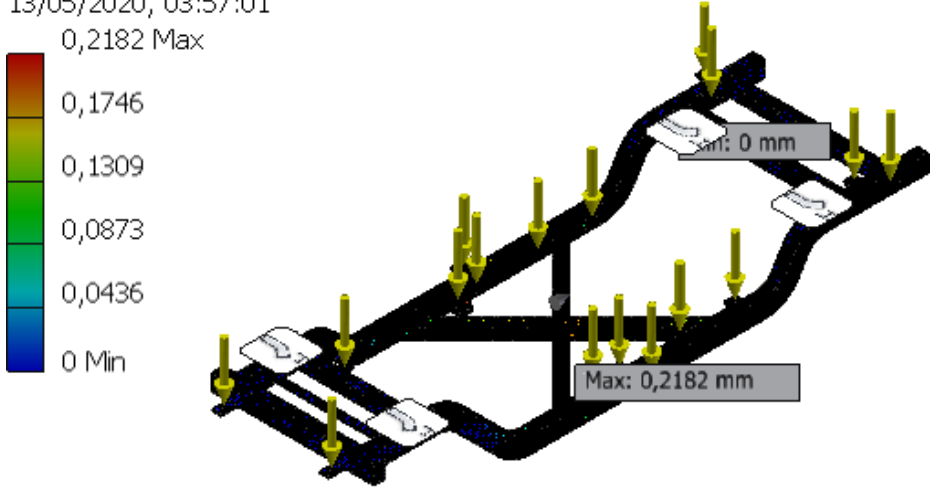

(b)

Nodes:893762

Elements:464237

Type: Safety Factor

Unit: ul

$13 / 05 / 2020,03: 56: 51$

$15 \mathrm{Max}$
$12,3 \mathrm{Min}$
9
6
3
0

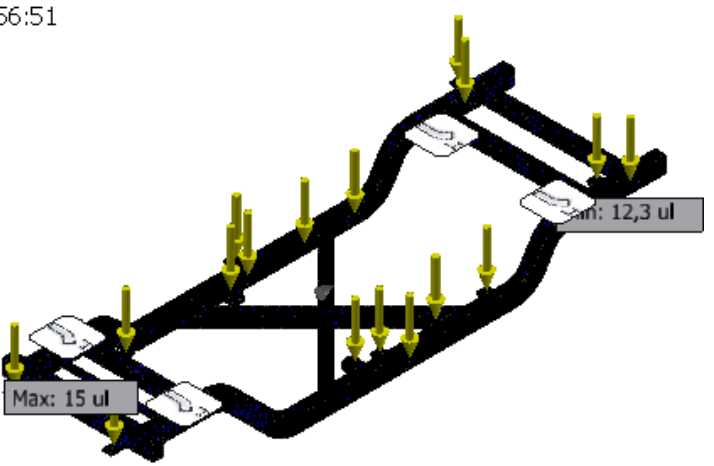

${ }_{z}$

(c)

Gambar 7. Hasil analisis dengan mesh view, (a) von Mises stress, (b) displacement dan (c) safety factor 
Febrian Arif Budiman dkk /Jurnal Rekayasa Mesin

p-ISSN: 1411-6863, e-ISSN: 2540-7678

Vol.16|No.1|100-108|April|2021

Tabel 4. Hasil simulasi

\begin{tabular}{llcc}
\hline \multirow{2}{*}{ No } & \multirow{2}{*}{ Data Stress Analysis } & \multicolumn{2}{c}{ Hasil simulasi } \\
\cline { 2 - 4 } 1. & Tegangan von mises $(\mathrm{MPa})$ & 20,33 & Min. \\
2. & Displacement $(\mathrm{mm})$ & 0,22 & 0 \\
3. & Safety Factor & 15 & 0 \\
\hline
\end{tabular}

Validasi hasil simulasi dilakukan dengan membandingkan hasil simulasi dengan jurnal yang membahas tentang tegangan von mises dan safety factor. Hasil simulasi pada penelitian ini menunjukkan bahwa tengangan von mises maksimum 20,33 MPa, nilai yang ada mendekati nilai tegangan von mises pada simulasi yang dilakukan oleh peneliti lain yang menghasilkan tegangan von mises sebesar 18,3 MPa. Untuk nilai safety factor pada penelitian yang dihasilkan minimum 12,3 dan maksimum 15, nilai ini mendekati nilai safety factor dari penelitian lain sebesar minimum 10.5 dan maksimum 15 [20]. Validasi perancangan dan simulasi nilai safety factor (pers. 1) juga menggunakan perhitungan manual. Perbedaan nilai safety factor ditunjukkan pada Tabel 5.

$S f=\frac{\text { yield stress }}{\text { calculated stress }}$

Tabel 5. Perbedaan Nilai Safety Factor

\begin{tabular}{|c|c|c|}
\hline \multirow{2}{*}{ Data Stress Analysis } & Hasil Stress Analysis & \multirow{2}{*}{ Persentase $(\%)$} \\
\hline & Komputasi & \\
\hline Safety Factor Min. & 12,97 & 1 \\
\hline
\end{tabular}

\section{Kesimpulan}

Berdasarkan hasil penelitian didapatkan simpulan bahwa desain chassis untuk kendaraan listrik tipe in-wheel dengan 6 penumpang memiliki tegangan von mises pada chassis minimum sebesar 0 dan maksimal 20,33 MPa, displacement minimum sebesar 0 dan maksimum sebesar 0,22, serta nilai safety factor minimum sebesar 12,3 dan maksimum sebesar 15. Berdasarkan hasil penelitian desain chassis yang telah dibuat dikategorikan aman secara teknis. Saran dalam penelitian berikutnya adalah dengan mengoptimasi penggunaan jenis material pada chassis.

\section{Daftar Pustaka}

[1] Budioyono, A., 2001, Pencemaran Udara: Dampak Pencemaran Udara Pada Lingkungan. Berika Dirgantara. Vol 2. No. 1, hal. 21-27.

[2] Fenton, J., Hodkinson, R., 2001, Lightweight Electric/Hybrid Vehicle Design, Elsevier.

[3] Fajri, P., Asaei, B., 2008, Plug-in hybrid conversion of a series hybrid electric vehicle and simulation comparison', 11th International Conference on Optimization of Electrical and Electronic Equipment, 2008. OPTIM 2008, IEEE, Mei hal.287-292.

[4] Sa'adah, Fitriyatus, A., Fauzi, A., Juanda, B., 2017, Peramalan Penyediaan dan Konsumsi Bahan Bakar Minyak Indonesia dengan Model Sistem Dinamik. Jurnal Ekonomi dan Pembangunan Indonesia. Vol. 17 No. 2, hal. 118137.

[5] Koca, E., Yasar, A., Bircan, D.A., 2015, Design, Analysis And Optimization Of Chassis For An Electric Vehicle. Ç.Ü Fen ve Mühendislik Bilimleri Dergisi Yil 2015 Cilt: 32-2, hal. 111-120.

[6] Boria, S., Pettinari, S., 2014, Mathematical design of electric vehicle impact attenuators: Metallic vs. composite material. Composite Structures, 115, hal. 51-59. 
Febrian Arif Budiman dkk /Jurnal Rekayasa Mesin p-ISSN: 1411-6863, e-ISSN: 2540-7678 Vol.16|No.1|100-108|April|2021

[7] Miller J.M., Emadi, A., Rajarathnam, A.V., Ehsani, M., 1999, Current status and future trends in More Electric Car power systems, Proc. 49th IEEE Conf. on Vehicular Technology, Houston, TX, 1999, hal. 1380-1384.

[8] Hugo, M., Sousa, T., Vale, Z., Faria, P., 2014, Evaluation of the electric vehicle impact in the power demand curve in a smart grid environment, Original Research Article Energy Conversion and Management, 82, hal. 268-282.

[9] Raslavičius, L, Starevičius, M., Keršys, A., Pilkauskas, K., dkk., 2014, Economic comparison of automobiles with electric and with combustion engines: An analytical study, Procedia-Social and Behavioral Sciences, 109, hal. 225230.

[10] Wahyudi, N., Fahrudi, Y.A., 2016, Studi Eksperimen Rancang Bangun Rangka Jenis Ladder Frame pada Kendaraan Sport. JEECAE. 1(1), hal. 71-72.

[11] Un-Noor, F., Padmanaban, S., Mihet-Popa, L., Mollah, M.N., Hossain, E., 2017, A Comprehensive Study of Key Electric Vehicle (EV) Components, Technologies, Challenges, Impacts, and Future Direction of Development. Energies, 10(8), 1217; hal. 1-82.

[12] Wahyudi, Setiadi, R., Sumbodo, W., Budiman, F.A., 2020, Mesin Hybrid. Deepublish: Yogyakarta.

[13] Ehsani, M., Gao, Y., Gay, S.E., Emadi, A., 2004, Modern Electric, Hybrid Electric, and Fuel Cell Vehicles. New York Washington, D.C: CRC Press.

[14] Shimizu, Hiroshi., Kiyomoto Kawakami and Yuko Kakizaki, 1997. Evaluation and Future development of the small EV "Luciole", EVS-14, Orlando.

[15] Shimizu, H., Kawakami, K., Kakizaki, Y., 2001, “KAZ” The Super Electric Vehicle, EVS18, Berlin.

[16] Masayuki, T., Ashikaga, T., Mizuno, T., 1997, Novel Motors and Controllers for High-Performance Electric Vehicle with Four In-Wheel Motors, IEEE Transactions on Industrial Electronics, Vol. 44, No. 1, pp. 28-38.

[17] Yan-e, Z., Jianwu, Z., Xu, H., 2008, Development of a High Performance Electric Vehicle with Four-IndependentWheel Drives, SAE 2008-01-1829.

[18] Kim, D., Shin, K., Kim, Y., Cheon, J., 2010, Integrated Design of In-Wheel Motor System on Rear Wheels for Small Electric Vehicle. World Electric Vehicle Journal, Vol. 4, Hal. 1-6.

[19] Rifki, I, Munadi, Ahmad, Z.K., Bayuseno, A.P., 2018, Analisis Displacement dan Tegangan von Mises Terhadap Chassis Mobil Listrik Gentayu. ROTASI. Vol. 20, No. 4. Hal. 231-236.

[20] Hidayat, T., Nazaruddin, Syafri, 2017, Perancangan dan Analisis Statik Chassis Kendaraan Shell Eco Marathon Tipe Urban Concept. Jurnal Online Mahasiswa, Vol. 4 No. 2, Hal. 1-6. 